\title{
Alleviation of drought stress by silicon supplementation in pistachio (Pistacia vera L.) plants
}

\author{
Ghader Habibi ${ }^{1}$, Roghieh Hajiboland ${ }^{2,3 *}$ \\ ${ }^{1}$ Biology Department \\ Payame Noor University \\ 19395-3697 Tehran, Iran \\ ${ }^{2}$ Center of Excellence for Biodiversity \\ ${ }^{3}$ Plant Science Department \\ Faculty of Natural Sciences, University of Tabriz \\ 51666-14779 Tabriz, Iran
}

\begin{abstract}
The effect of silicon ( $\mathrm{Si}$ ) supplementation $\left(0.35 \mathrm{~g} \mathrm{Na}_{2} \mathrm{SiO}_{3} \mathrm{~kg}^{-1}\right.$ soil, $2.73 \mathrm{mmol} \mathrm{Si} \mathrm{kg} \mathrm{kg}^{-1}$ soil) was studied in drought-stressed pistachio (Pistacia vera L. 'Ahmadaghaii') plants under field conditions. Silicon treatment significantly increased plant dry weight and relative water content under drought stress. The application of Si for drought-stressed plants improved the maximum quantum yield of PSII. A reduction in the net assimilation rate due to drought stress was alleviated by Si application, accompanied by an increase in stomatal conductance. Silicon treatment resulted in higher catalase and superoxide dismutase activities and lower lipid peroxidation in the leaves of drought-stressed plants. The results suggest that supplementation of water-deficient pistachio plants with Si alleviates the adverse effects of drought due to its enhancement of photochemical efficiency and photosynthetic gas exchange, as well as an activation of the antioxidant defence capacity in this species.
\end{abstract}

Key words: antioxidant defence system, net $\mathrm{CO}_{2}$ assimilation rate, quantum yield of PSII, relative water content

\begin{abstract}
Abbreviations:
APX: ascorbate peroxidase, CAT: catalase, Chl: chlorophyll, DW: dry weight, $\Phi_{\text {PSII }}$ : effective quantum yield of PSII, FC: field capacity, FW: fresh weight, MDA: malondialdehyde, $F v / F m$ : maximum quantum yield of PSII, $A$ : net assimilation rate, $E$ : net transpiration rate, $q N$ : non-photochemical quenching, $q P$ : photochemical quenching, POD: peroxidase, PSII: photosystem II, ROS: reactive oxygen species, Si: silicon, $g_{s}$ : stomatal conductance, SOD: superoxide dismutase, WUE: water use efficiency
\end{abstract}

\section{INTRODUCTION}

Abiotic stresses such as drought, high salinity and extreme temperatures are major causes of crop losses worldwide. Drought is an important environmental stress that adversely affects plants growth and causes reduction of growth rate, stem elongation, leaf expansion and stomatal movements (Chaves et al. 2003).

Drought stress triggers production of reactive oxygen species (ROS) that cause oxidative damage to proteins, membrane lipids and other cellular components. To keep this damage to a minimum,

\footnotetext{
*Corresponding author.

Tel.: +98 41133560 31; fax: +98 41133560 27;

e-mail: ehsan@tabrizu.ac.ir (R. Hajiboland).
} 
plants possess enzymatic and non-enzymatic antioxidative defence systems. Enzymes such as superoxide dismutase (SOD), ascorbate peroxidase (APX) and catalase (CAT) play an important role against oxidative stress (Apel and Hirt 2004). Under drought conditions, the increased activity of antioxidant enzymes is important for plants stress tolerance (Gong et al. 2005).

It has been well documented that elements such as aluminium, cobalt, sodium, selenium, and silicon positively affect plant growth and stress resistance (Broadley et al. 2012). Although not considered an essential element for plants growth and metabolism, silicon ( $\mathrm{Si}$ ) is beneficial for most of the higher plants, especially under stressful conditions (Ma 2004, Epstein 2009). Silicon alleviates the effects of salt stress, high temperature and heavy metal toxicity in plants (Shi et al. 2005, Liang et al. 2007, Shen et al. 2010).

Silicon application to crops has been reported to enhance their tolerance of water stress (Ma 2004, Hattori et al. 2007). The mechanisms that underlie Si-mediated alleviation of damages caused by drought stress are poorly understood (Chen et al. 2011). Several authors have suggested that $\mathrm{Si}$ causes an improvement of water use efficiency and stimulates enzymatic and nonenzymatic antioxidative defence systems (Liang et al. 2003, Hattori et al. 2005, Gunes et al. 2007, Liang et al. 2007, Cooke and Leishman 2011). An increase in the production of antioxidants and a decline of ROS generation mediated by Si causes a reduction of photo-oxidative damage, maintenance of chloroplast membrane integrity and thus enhancement of plant drought tolerance (Waraich et al. 2011). Silicon fertilisation leads to increased volume and weight of roots (Matichenkov et al. 2000, Ahmed et al. 2011, Sonobe et al. 2011) and decreases water loss via transpiration because of the silicification of leaf surfaces (Cooke and Leishman 2011) that decreases cuticular transpiration as well as a reduction in the diameter of stomatal pores (Snyder and Matichenkov 2007). All of these factors can ultimately enhance drought resistance of Si-supplemented plants.

Pistachio (Pistacia vera L.) is one of the most important tree crops in the Mediterranean climate, where plants are frequently subjected to prolonged drought periods (Rieger 1995, Gijón et al. 2011). Pistachio is an important crop in Iran and the area of pistachio orchards in the country is more than 360,000 ha, with about 13 million pistachio trees
(Sheibani et al. 1994, Banakar and Ranjbar 2010) comprising 60 different varieties.

Pistachio is a drought tolerant species (Gijón et al. 2010, 2011). However, responses of pistachio to water stress have not been adequately characterised. There are few studies on the water relations of this species (Gijón et al. 2010). It has been shown that drought tolerance of pistachio plants was higher than some other fruit trees and other typical xerophytes species (Gijón et al. 2011). Despite its potentially high drought tolerance, any amelioration of droughtinduced growth suppression in this species requires further improvement of plant ability to maintain homeostasis in water relations, especially during the summer season. Previous studies on the effect of Si supplementation in drought-stressed plants have mainly focused on Gramineae species (Gong et al. 2005, 2008, Ahmed et al. 2011, Sonobe et al. 2011). We hypothesised that, similar to that in Gramineae, Si supply will improve drought tolerance of pistachio plants, a drought-resistance dicotyledonous species.

The aim of this work was to study the mechanisms for alleviating the effect of $\mathrm{Si}$ in drought-stressed pistachio plants with regard to Si-mediated alteration of some physiological characteristics under water scarcity. For this purpose, we examined growth, relative water content, chlorophyll (Chl) fluorescence parameters and gas exchange patterns, and studied the effect of $\mathrm{Si}$ on the antioxidant defence system during drought stress.

\section{MATERIAL AND METHODS}

\section{Plant growth and treatments}

Seeds of pistachio (Pistacia vera L. 'Ahmadaghaii') were sown in the top parts of cylindrical plastic pots; four seeds were planted in each pot. Pots were $14 \mathrm{~cm}$ in diameter and $105 \mathrm{~cm}$ in depth, filled with $15 \mathrm{~kg}$ sandy loam soil ( $\mathrm{pH} 7.6, \mathrm{EC} 1.32 \mathrm{dS} \mathrm{m}^{-1}$, field capacity [FC] 23\%, organic carbon (OC) 1.09 $\%$ ). For the basal fertilisation, $200 \mathrm{mg}$ nitrogen $\mathrm{kg}^{-1}$ soil as $\mathrm{NH}_{4} \mathrm{NO}_{3}$ and 50 and $62.5 \mathrm{mg}$ phosphorus and potassium $\mathrm{kg}^{-1}$ soil as $\mathrm{KH}_{2} \mathrm{PO}_{4}$ were applied. Before filling the pots, soils of $\mathrm{Si}$ treatments were fertilised with $0.35 \mathrm{~g}$ sodium metasilicate $\left(\mathrm{Na}_{2} \mathrm{SiO}_{3}\right)$ $\mathrm{kg}^{-1}$ soil (3.44 mmol dm ${ }^{-3}$ soil, $2.73 \mathrm{mmol} \mathrm{kg}{ }^{-1}$ soil). Equimolar concentrations of $\mathrm{NaCl}$ were applied for balancing $\mathrm{Na}$ amounts in the soils of control pots without Si. After emergence, the seedlings were thinned to one plant per pot and plants were watered every 4-5 days to maintain at $70 \%$ of FC before starting treatments. Seventy-five days after sowing, different watering treatments including 
the control $(70 \% \mathrm{FC})$ and drought $(35 \% \mathrm{FC})$ were applied. Four independent pots were counted as the four replicates for each treatment combination. Plants were grown under field conditions located near the city of Miandoab, NW Iran (46. $6^{\prime} \mathrm{E}$ and $36^{\circ} 46^{\prime} \mathrm{N}$ ) with day/night temperature of 20-35/17$20^{\circ} \mathrm{C}$, relative humidity of $25-45 \%$ and daily photon

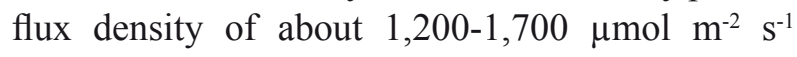
throughout the experimental period.

\section{Plant harvest, Si analysis and measurement of relative water content ( $R W C$ )}

Plants were harvested 45 days after starting different watering regimes (120 days after sowing). Shoots were washed with distilled water, blotted dry on filter paper and after determination of fresh weight (FW) were dried for $48 \mathrm{~h}$ at $70^{\circ} \mathrm{C}$ for determination of dry weight (DW). Leaves were prepared for determination of Si (Jaiswal 2004) using Inductively-Coupled Plasma-Atomic Emission Spectrometry (ICP-AES, INTEGRA XL 2, GBC, Australia). Relative water content (RWC) was measured in the leaves harvested at $1 \mathrm{~h}$ after light on in the field and calculated according to the formula: $(\mathrm{FW}-\mathrm{DW}) /(\mathrm{TW}-\mathrm{DW}) \times 100$ where $\mathrm{TW}$ is turgid weight. Before the harvest, leaf $\mathrm{Chl}$ and gas exchange parameters were determined in the second or third youngest, fully developed leaves.

\section{Measurements of Chl fluorescence parameters and photosynthetic gas exchange}

Chlorophyll fluorescence parameters were recorded using a portable fluorometer (OSF1, ADC Bioscientific Ltd., UK) for both dark adapted and light adapted leaves. Leaves were acclimated to dark for $30 \mathrm{~min}$ using leaf clips before measurements were taken. Initial $\left(F_{0}\right)$, maximum $\left(F_{m}\right)$, variable $\left(F_{v}=F_{m}-F_{0}\right)$ fluorescence as well as maximum quantum yield of photosystem II (PSII) $\left(F_{v} / F_{m}\right)$ were recorded. Light adapted leaves were used for the measurement of steady state $\left(F_{s}\right)$ and maximum $\left(F_{m}{ }_{m}\right)$ fluorescence. Calculations were made for $F^{\prime}{ }_{0}\left(F^{\prime}{ }_{0}=\right.$ $\left.F_{0} /\left[\left(F_{v} / F_{m}\right)+\left(F_{0} / F^{\prime}{ }_{m}\right)\right]\right)$, photochemical quenching, $q P\left[\left(F_{m}{ }_{m}-F_{s}\right) /\left(F_{m}{ }_{m}-F_{0}^{\prime}\right)\right]$, non-photochemical quenching, $q N\left(1-\left[\left(F_{m}^{\prime}-F_{0}^{\prime}\right) /\left(F_{m}-F_{0}\right)\right]\right)$ and effective quantum yield of PSII, $\Phi_{\text {PSII }}\left[\left(F_{m}{ }_{m}-F_{s}\right) /\right.$ $\left.F_{m}{ }_{m}\right]$ (Maxwell and Johnson 2000). Net $\mathrm{CO}_{2}$ fixation $\left(A, \mu \mathrm{mol} \mathrm{m} \mathrm{s}^{-1}\right)$, transpiration rate $\left(E, \mu \mathrm{mol} \mathrm{m} \mathrm{m}^{-2} \mathrm{~s}^{-1}\right)$ and stomatal conductance to water vapour $\left(g_{s}\right.$, mol $\left.\mathrm{m}^{-2} \mathrm{~s}^{-1}\right)$ were measured with a calibrated portable gas exchange system (LCA-4, ADC Bioscientific Ltd., $\mathrm{UK}$ ) after $5 \mathrm{~h}$ into the light period under a photon flux density of about $1,500 \mu \mathrm{mol} \mathrm{m} \mathrm{m}^{-2} \mathrm{~s}^{-1}$.

\section{Assay of enzyme activity and related metabolites}

Activity of superoxide dismutase (SOD, EC 1.15.1.1), peroxidase (POD, EC 1.11.1.7), catalase (CAT, EC 1.11.1.6) and ascorbate peroxidase (APX, EC 1.11.1.11) were determined according to methods described elsewhere (Habibi and Hajiboland 2010). Lipid peroxidation was estimated from the amount of malondialdehyde (MDA) formed in a reaction mixture containing thiobarbituric acid. The concentration of hydrogen peroxide $\left(\mathrm{H}_{2} \mathrm{O}_{2}\right)$ was determined using the potassium titaniumoxalate method (Habibi and Hajiboland 2010). Soluble protein was estimated using the Bradford method (1976).

Statistical analyses were carried out using sigma stat (3.5) with the Tukey test $(\mathrm{p}<0.05)$.

\section{RESULTS}

The fresh and dry weight of plants decreased significantly under drought stress conditions in both $\mathrm{Si}$ treatments. However, the extent of reduction in plant biomass was lower in the presence of $\mathrm{Si}$. Silicon treatment did not influence plants' FW, DW and RWC under well-watered conditions, while it significantly increased these parameters under drought conditions. The silicon concentration of leaves was significantly higher in the Si-treated plants (Tab. 1).

Table 1. Leaf fresh (FW) and dry weight (DW), relative water content (RWC) and Si concentration in pistachio plants grown for 45 days under control and drought conditions with or without $\mathrm{Si}$ application. Each value is the mean $\pm \mathrm{SD}$ of four replicates

\begin{tabular}{llcccc}
\hline Treatments & & FW $\left(\right.$ g plant $\left.^{-1}\right)$ & DW $\left(\right.$ g plant $\left.^{-1}\right)$ & RWC $(\%)$ & $\begin{array}{c}\text { Si concentration } \\
\left(\mathrm{mg} \mathrm{g}^{-1} \mathrm{DW}\right)\end{array}$ \\
\hline \multirow{2}{*}{ Control } & $-\mathrm{Si}$ & $6.35 \pm 0.22^{\mathrm{a}}$ & $2.66 \pm 0.24^{\mathrm{a}}$ & $67.2 \pm 1.71^{\mathrm{a}}$ & $1.47 \pm 0.22^{\mathrm{b}}$ \\
& $+\mathrm{Si}$ & $6.60 \pm 0.55^{\mathrm{a}}$ & $2.73 \pm 0.31^{\mathrm{a}}$ & $68.5 \pm 3.10^{\mathrm{a}}$ & $2.24 \pm 0.20^{\mathrm{a}}$ \\
\multirow{2}{*}{ Drought } & $-\mathrm{Si}$ & $4.45 \pm 0.34^{\mathrm{c}}$ & $1.52 \pm 0.17^{\mathrm{c}}$ & $51.0 \pm 3.46^{\mathrm{c}}$ & n.d. $^{*}$ \\
& $+\mathrm{Si}$ & $5.52 \pm 0.23^{\mathrm{b}}$ & $2.09 \pm 0.23^{\mathrm{b}}$ & $61.0 \pm 2.94^{\mathrm{b}}$ & n.d. \\
\hline
\end{tabular}

Data of each column indicated by the same letters are not significantly different $(\mathrm{p}<0.05)$

*n.d.: not determined 
Table 2. Photochemical and gas exchange parameters* in pistachio plants grown for 45 days under control and drought conditions without or with $\mathrm{Si}$ application. Each value is the mean $\pm \mathrm{SD}$ of four replicates

\begin{tabular}{lcccc}
\hline \multirow{2}{*}{ Photochemistry } & \multicolumn{2}{c}{ Control } & \multicolumn{2}{c}{ Drought } \\
\cline { 2 - 5 } & $-\mathrm{Si}$ & $+\mathrm{Si}$ & $-\mathrm{Si}$ & $+\mathrm{Si}$ \\
\hline$F_{v} / F_{m}$ & $0.78 \pm 0.01^{\mathrm{a}}$ & $0.79 \pm 0.01^{\mathrm{a}}$ & $0.66 \pm 0.04^{\mathrm{c}}$ & $0.71 \pm 0.01^{\mathrm{b}}$ \\
$q P$ & $0.89 \pm 0.03^{\mathrm{a}}$ & $0.89 \pm 0.05^{\mathrm{a}}$ & $0.95 \pm 0.04^{\mathrm{a}}$ & $0.87 \pm 0.08^{\mathrm{a}}$ \\
$q N$ & $0.19 \pm 0.09^{\mathrm{ab}}$ & $0.12 \pm 0.07^{\mathrm{b}}$ & $0.27 \pm 0.05^{\mathrm{a}}$ & $0.26 \pm 0.01^{\mathrm{a}}$ \\
$\Phi_{\text {PSII }}$ & $0.68 \pm 0.05^{\mathrm{ab}}$ & $0.69 \pm 0.04^{\mathrm{a}}$ & $0.57 \pm 0.06^{\mathrm{b}}$ & $0.57 \pm 0.06^{\mathrm{b}}$ \\
\hline Gas exchange & & & & $2.72 \pm 0.17^{\mathrm{b}}$ \\
\hline$A\left(\mu \mathrm{mol} \mathrm{CO}_{2} \mathrm{~m}^{-2} \mathrm{~s}^{-1}\right)$ & $3.90 \pm 0.23^{\mathrm{a}}$ & $4.87 \pm 0.91^{\mathrm{a}}$ & $1.47 \pm 0.44^{\mathrm{c}}$ & $0.50 \pm 0.10^{\mathrm{b}}$ \\
$E\left(\mathrm{mmol} \mathrm{H}_{2} \mathrm{O} \mathrm{m}^{-2} \mathrm{~s}^{-1}\right)$ & $0.60 \pm 0.01^{\mathrm{b}}$ & $0.80 \pm 0.10^{\mathrm{a}}$ & $0.30 \pm 0.10^{\mathrm{c}}$ & $0.17 \pm 0.05^{\mathrm{bc}}$ \\
$g_{s}\left(\mathrm{~mol} \mathrm{~m}^{-2} \mathrm{~s}^{-1}\right)$ & $0.23 \pm 0.01^{\mathrm{b}}$ & $0.33 \pm 0.11^{\mathrm{a}}$ & $0.10 \pm 0.02^{\mathrm{c}}$ & $5.60 \pm 1.10^{\mathrm{a}}$ \\
$W U E\left(\mu \mathrm{mol} \mathrm{mmol}^{-1}\right)$ & $6.30 \pm 0.50^{\mathrm{a}}$ & $6.20 \pm 0.60^{\mathrm{a}}$ & $4.60 \pm 2.30^{\mathrm{a}}$ & \\
\hline
\end{tabular}

Data of each row indicated by the same letters are not significantly different $(\mathrm{p}<0.05)$

*Explanations: see Abbreviations

Drought stress decreased the maximum quantum yield of PSII $\left(F_{v} / F_{m}\right)$ and effective quantum yield of $\operatorname{PSII}\left(\Phi_{\mathrm{PSII}}\right)$. In contrast, photochemical quenching $(q P)$ was not influenced by different watering treatments and non-photochemical quenching $(q N)$ rather increased under drought conditions. Similar with plant growth data, $\mathrm{Si}$ supplementation did not affect the photochemical parameters in wellwatered plants but improved the $F_{v} / F_{m}$ ratio and decreased $q N$ in drought-stressed ones (Tab. 2).
The net assimilation rate $(A)$, transpiration rate $(E)$ and stomatal conductance $\left(g_{s}\right)$ all were inhibited by exposure of plants to drought stress. Application of Si influenced these parameters under both watering regimes. In well-watered plants, the net assimilation rate was increased slightly due to $\mathrm{Si}$ application; this effect was significant for $E$ and $g_{s}$. The effect of Si application was more prominent under drought conditions. Because of a simultaneous increase of the net assimilation rate and transpiration following elevated stomatal

Table 3. The results of two-way ANOVA test (mean of squares) for the effect of different treatments and their interactions on various physiological parameters* in pistachio plants

\begin{tabular}{|c|c|c|c|c|}
\hline Parameters & Drought & Silicon & $\mathrm{D} \times \mathrm{Si}$ & Residual \\
\hline FW & $12882 * * *$ & $2401 * *$ & $1122 *$ & 214.1 \\
\hline DW & $870.2 * * *$ & $144.0 * *$ & $110.2 * *$ & 8.708 \\
\hline RWC & $564.0 * * *$ & $126.6^{* *}$ & $76.56 * *$ & 8.310 \\
\hline$F v / F m$ & $0.051 * * *$ & $0.002^{\text {n.s. }}$ & $0.001^{\text {n.s. }}$ & 0.000 \\
\hline$q P$ & $0.001^{\text {n.s. }}$ & $0.007^{\text {n.s. }}$ & $0.005^{\text {n.s. }}$ & 0.003 \\
\hline$q N$ & $0.050 *$ & $0.007^{\text {n.s. }}$ & $0.003^{*}$ & 0.006 \\
\hline$\Phi$ PSII & $0.056 * * *$ & $0.000^{\text {n.s. }}$ & $0.000^{\text {n.s. }}$ & 0.003 \\
\hline$A$ & $20.95 * * *$ & $4.98 * * *$ & $0.082^{\text {n.s. }}$ & 0.278 \\
\hline$E$ & $0.303 * * *$ & $0.106^{* *}$ & $0.000^{\text {n.s. }}$ & 0.008 \\
\hline$g_{s}$ & $0.091 * * *$ & $0.028 * *$ & $0.000^{\text {n.s. }}$ & 0.040 \\
\hline WUE & $5.907^{\text {n.s. }}$ & $0.824^{\text {n.s. }}$ & $1.220^{\text {n.s. }}$ & 1.818 \\
\hline SOD & $322.9 * * *$ & $112.8^{* * *}$ & $7.570 * *$ & 1.520 \\
\hline POD & $0.015^{\text {n.s. }}$ & $0.109^{* * *}$ & $0.003^{\mathrm{ns}}$ & 0.003 \\
\hline CAT & $160.1^{\text {n.s. }}$ & $2011 * * *$ & $1467 * *$ & 106.6 \\
\hline APX & $0.661 * * *$ & $0.001^{\mathrm{ns}}$ & $0.002^{\text {n.s. }}$ & 0.012 \\
\hline MDA & $139.3 * * *$ & $82.45^{* *}$ & $95.14 * *$ & 5.944 \\
\hline $\mathrm{H}_{2} \mathrm{O}_{2}$ & $0.360 * * *$ & $0.022 *$ & $0.018^{*}$ & 0.003 \\
\hline
\end{tabular}

n.s.: non-significant, according to Tukey test, $* * * \mathrm{p}<0.001, * * \mathrm{p}<0.01, * \mathrm{p}<0.05$

*Explanations: see Abbreviations 
conductance by Si treatment, water use efficiency (WUE) remained unchanged (Tab. 2).

Drought stress caused a significant increase in the activity of SOD and APX, but did not change the activity of POD while it rather decreased that of CAT (Fig. 1). The application of Si stimulated SOD and POD activity under well-watered conditions, but did not influence CAT and APX activity. Under drought conditions, $\mathrm{Si}$ application caused a significant increase in the activity of all analysed antioxidant enzymes with the exception of APX. Drought stress resulted in a significant accumulation of MDA and $\mathrm{H}_{2} \mathrm{O}_{2}$. Although Si application had no effect under well-watered conditions, Si supplemented plants maintained lower MDA content under drought stress (Fig. 1).

Two-way analysis of variance of the effects of drought and $\mathrm{Si}$ application revealed that $\mathrm{Si}$ influenced the majority of the measured physiological parameters in pistachio leaves (Tab. 3). A significant interaction effect between Si and drought on plant growth, RWC, SOD and
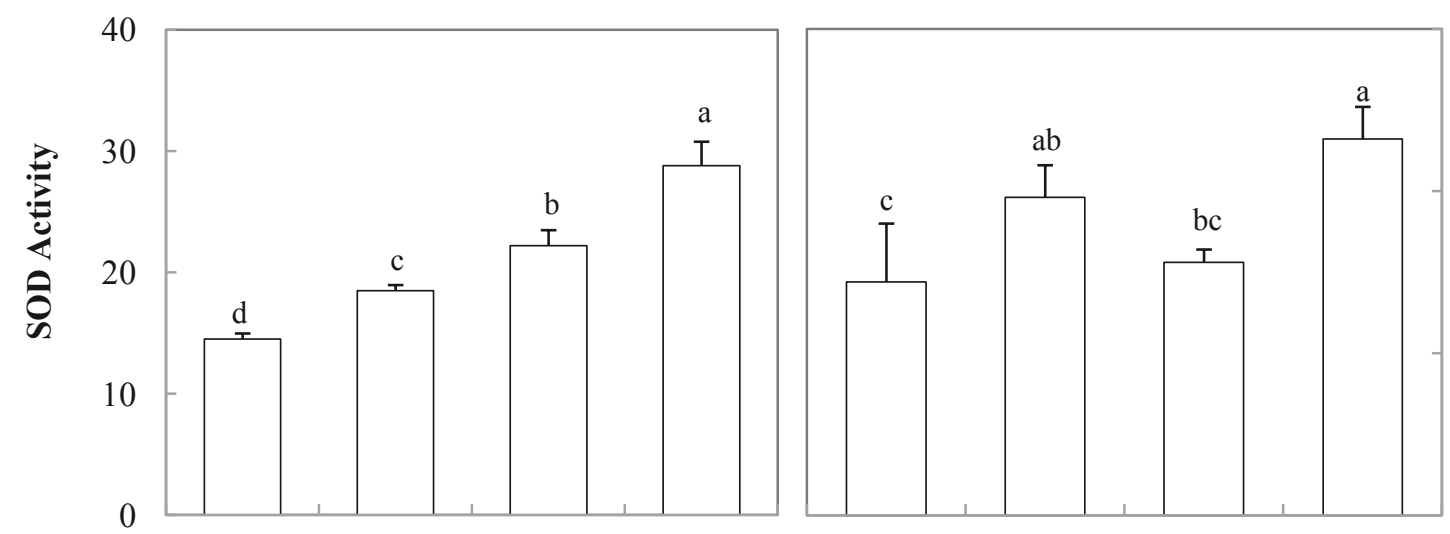

0.75
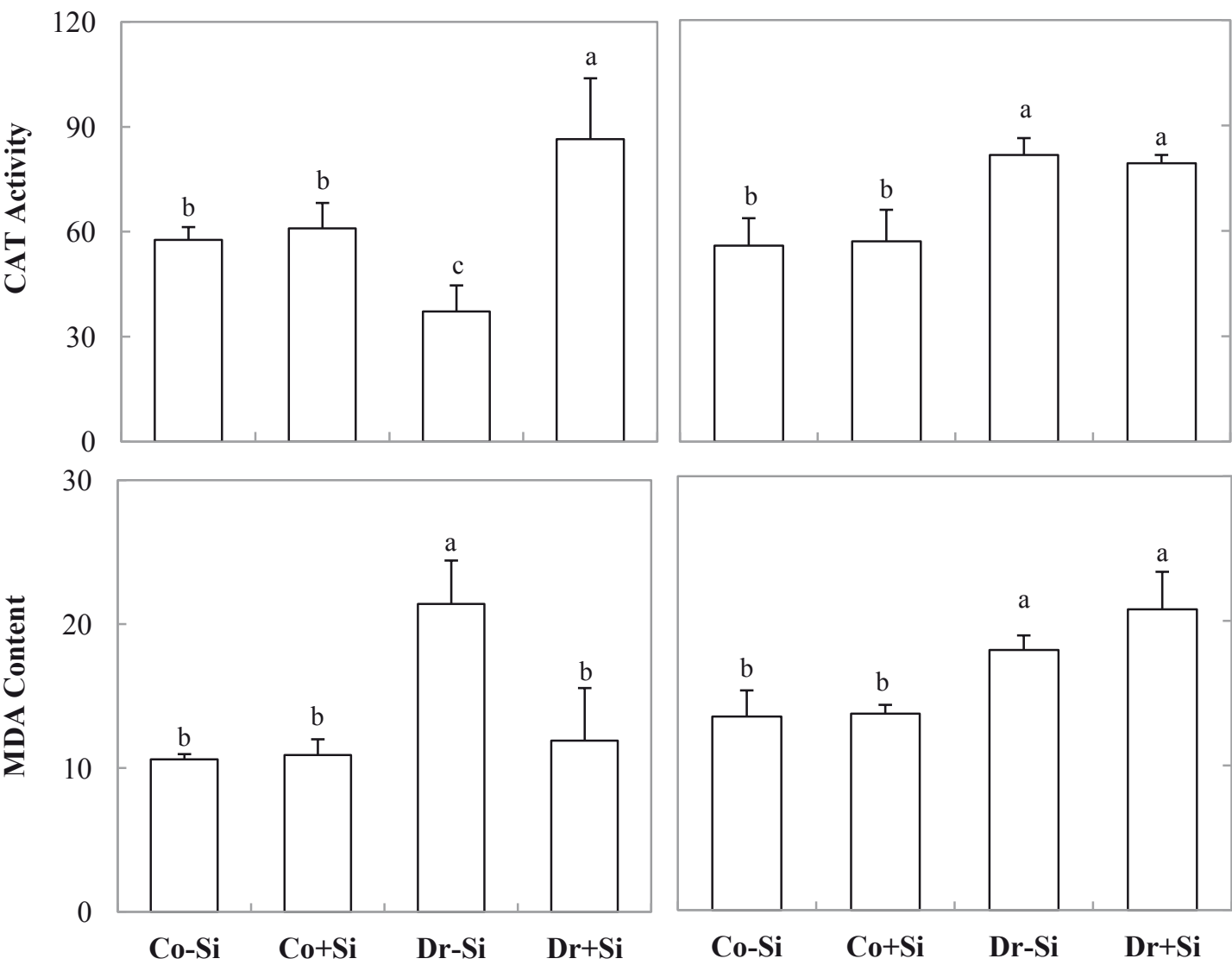

Figure 1. The specific activity of SOD ( $\mathrm{U} \mathrm{mg}^{-1}$ protein), POD $\left(\mu \mathrm{mol} \mathrm{mg} \mathrm{m}^{-1}\right.$ protein $\left.\mathrm{min}^{-1}\right)$, CAT $\left(\mu \mathrm{mol} \mathrm{mg}^{-1} \mathrm{protein}\right.$ $\left.\mathrm{min}^{-1}\right)$, APX $\left(\mu \mathrm{mol} \mathrm{mg} \mathrm{m}^{-1}\right.$ protein $\left.\mathrm{min}^{-1}\right)$ and concentration of MDA and $\mathrm{H}_{2} \mathrm{O}_{2}\left(\mu \mathrm{mol} \mathrm{g}^{-1} \mathrm{FW}\right)$ in pistachio plants grown for 45 days under control and drought conditions with or without Si application. Each value is the mean $\pm \mathrm{SD}$ of four replicates. Bars indicated with the same letter are not significantly different $(p<0.05)$. Explanations: see Abbreviations. 
CAT activity and MDA content also indicated that Si influenced these parameters mainly in droughtstressed plants.

\section{DISCUSSION}

Drought stress inhibited dry matter production of pistachio plants and $\mathrm{Si}$ application significantly improved plant growth only under drought conditions. Plant growth improvement by $\mathrm{Si}$ application under drought conditions has been documented in monocot and dicot species including wheat (Gong et al. 2005), rice (Chen et al. 2011) and soybean (Shen et al. 2010) plants. Silicon has been proven to be beneficial for the healthy growth and development of many plant species, particularly Gramineae (Broadley et al. 2012). The beneficial effects of $\mathrm{Si}$ are particularly distinct in plants exposed to various environmental stresses. Extensive studies have been performed in order to find possible mechanism(s) for Si-enhanced tolerance of higher plants to abiotic stresses (for review, see Liang et al. 2007, Hajiboland 2012). Rapid progress has been also made in mechanisms for Si uptake and transport in higher plants (Ma and Yamaji 2006).

Chlorophyll fluorescence parameters provide information about PSII photochemistry and reveal possible alterations in leaf photosynthetic activity under stress conditions (Maxwell and Johnson 2000). In this study, it was shown that drought stress declined maximum PSII efficiency $\left(F_{v} / F_{m}\right)$ while increasing non-photochemical quenching $(q N)$. The $F_{v} / F_{m}$ is generally considered a parameter very resistant to stress conditions and the decline of $F_{v} / F_{m}$ values indicates serious damage to PSII (Maxwell and Johnson 2000). The destruction of the photosynthetic apparatus in drought-stressed plants is mainly the result of photo-inhibition (Cornic 1994). Photo-inhibition has been defined as the inhibition of photosynthesis caused by excessive radiation energy (Krause and Jahns 2004). Photo-inhibition may damage the photosynthetic apparatus, or may cause a slow and reversible reduction of photosynthetic efficiency that leads to a partial loss of capacity to convert radiation energy into net assimilate production. An excess of light energy could be dissipated as heat through $q N$ (Krause and Jahns 2004) as was observed in drought-stressed plants in this study.

Stomatal closure that limits $\mathrm{CO}_{2}$ availability for dark reactions may be one of the mechanisms for photo-inhibition in drought-stressed leaves in this study. Stomatal control of water loss has been identified as an early event in plant response to water stress (Reddy et al. 2004). On the other hand, photosynthesis can be inhibited under drought conditions even when the stomatal influence is eliminated(leafdisks without epidermis), suggesting that factors other than low $\mathrm{CO}_{2}$ availability affect photosynthesis (Tang et al. 2002). The reduction of $A$ in drought-stressed plants in this study could not only be attributed to the stomatal limitation but may also be explained by inhibited leaf photochemistry as well as metabolic impairment; i.e. the reduction of Rubisco activity and ATP synthesis (Reddy et al. 2004). Activation of the carbon reduction cycle may be especially sensitive to drought (Reddy et al. 2004). An increased net photosynthetic rate due to Si treatment was observed in the leaves of sorghum (Hattori et al. 2005, Ahmed et al. 2011), wheat (Gong et al. 2005) and soybean (Shen et al. 2010) plants under water stress, which might be associated with an increase in the activity of photosynthetic enzymes such as RuBP carboxylase (Adatia and Besford 1986).

Supplementation of plants with Si slightly or significantly elevated stomatal conductance under both watering regimes. Elevated stomatal conductance particularly in drought-stressed plants may be one of the mechanisms for maintaining dry matter production in plants experiencing water scarcity. It has been demonstrated that drought-tolerant species control stomatal function to allow some carbon fixation during stress, thus improving water use efficiency (Yordanov et al. 2003). On the other hand, providing optimum $\mathrm{CO}_{2}$ concentration for carbon reactions may prevent photo-inhibition, which was clearly reflected in the significantly higher $F_{v} / F_{m}$ value in the presence of $\mathrm{Si}$ in drought-stressed pistachio plants. Although in Si-treated plants the $F_{v} / F_{m}$ value was still lower than in well-watered plants, it was significantly higher than in the drought-stressed plants without $\mathrm{Si}$ treatment. The role of Si-mediated increase in the leaf anthocyanins and soluble phenols, which act in protecting chloroplasts against excess light (Goto et al. 2003), could not be excluded. Evidence on the effect of Si treatment on leaf photochemical parameters is very rare and restricted to Gramineae species (Gao et al. 2011).

Although Si-supplemented plants were less conservative in relation to water loss following elevated stomatal conductance, higher RWC implied that Si may help plants to maintain their water balance despite greater water loss, most likely because of higher water uptake. It has been 
demonstrated that the application of Si improves the water status of stressed plants (Shen et al. 2010). The application of Si increased root water uptake of sorghum plants without affecting the shoot/root ratio (Hattori et al. 2008, Ahmed et al. 2011, Sonobe et al. 2011). More detailed studies are needed for analysing the effect of $\mathrm{Si}$ on root water uptake capacity in pistachio.

Antioxidant enzymes protect plant structural and molecular components from the effects of ROS accumulated during drought stress (Apel and Hirt 2004). Apart from the drought-induced increase in the activity observed for all examined antioxidant enzymes, SOD and CAT activity was significantly higher in drought-stressed plants supplemented with Si compared to plants without Si addition. SOD activity increased upon $\mathrm{Si}$ treatment even under well-watered conditions, and further increase under drought conditions may confer plants greater protection against superoxide radicals under water deficiency conditions. The primary scavenger of ROS is SOD, which converts superoxide to hydrogen peroxide and oxygen (Ślesak et al. 2007). The activation of antioxidant enzymes including SOD, CAT, glutathione reductase and dehydroascorbate reductase by Si supplementation has been reported in some plant species (Gong et al. 2005, 2008, Liang et al. 2003, 2007).

The efficiency of antioxidant enzymes in the preservation of membranes against ROS injury was visibly reflected in the stable amount of MDA in drought-stressed plants and is likely another reason for the protective effect of Si on the photochemistry of leaves observed in this study.

Under stress conditions, $\mathrm{H}_{2} \mathrm{O}_{2}$ in plant tissues can be a precursor of a highly reactive oxygen species (Ślesak et al. 2007). The accumulation of $\mathrm{H}_{2} \mathrm{O}_{2}$ affects the structure and integrity of plasma membranes by influencing the stress-dependent peroxidation of membrane lipids (Liang et al 2003, 2006). In this research, despite the increasing CAT and APX activity, plants accumulated higher levels of $\mathrm{H}_{2} \mathrm{O}_{2}$ under drought conditions likely because of enhanced photorespiration.

\section{CONCLUSIONS}

1. Under drought conditions, Si supplementation improved plant growth and increased relative water content, maximum quantum yield of PSII and net assimilation rate. However, under wellwatered conditions these parameters were not influenced by Si supplementation.
2. Supplementation of plants with Si elevated the stomatal conductance of leaves, which caused an improved $\mathrm{CO}_{2}$ fixation capacity under water scarcity. This effect also resulted in providing an optimum $\mathrm{CO}_{2}$ concentration for carbon reactions that in turn prevented photo-inhibition. Though there was higher water loss through transpiration in Si-treated plants under drought conditions, increased relative water content implied an enhanced water uptake capacity of roots.

3. Silicon treatment caused an activation of antioxidant enzymes, reflected in the stable amount of lipid peroxidation, while malondialdehyde content dramatically increased in drought-stressed leaves in the absence of Si.

\section{REFERENCES}

Adatia M.H., Besford R.T., 1986. The effects of silicon on cucumber plants grown in recirculating nutrient solution. Ann. Bot. 58: 343-351.

Ahmed M., Hassen F.U., Qadeer U., Aslam M.A., 2011. Silicon application and drought tolerance mechanism of sorghum. Afr. J. Agric. Res. 6: 594-607.

Apel K., Hirt H., 2004. Reactive oxygen species: Metabolism, oxidative stress and signal transduction. Annu. Rev. Plant Biol. 55: 373-399.

Banakar M.H., Ranjbar G.H., 2010. Evaluation of salt tolerance of pistachio cultivars at seedling stage. American-Eurasian. J. Agric. Environ. Sci. 9: 115-120.

BRADFORD M.M., 1976. A rapid and sensitive method for quantitation of microgram quantities of protein utilizing the principle of protein-dye binding. Anal. Biochem. 72: 248-254.

Broadley M., Brown P., Cakmak I., Ma J.F., Rengel Z., ZHAO F., 2012. Beneficial elements. In: Marschner's mineral nutrition of higher plants. $3^{\text {rd }}$ edition. P. Marschner (ed.), UK, London, Academic Press, London: 249-269.

Chaves M.M., Marco J.P., Periera S., 2003. Understanding plant responses to drought from genes to the whole plant. Funct. Plant Biol. 30: 239-64.

Chen W., Yao X., CAI K., Chen J., 2011. Silicon alleviates drought stress of rice plants by improving plant water status, photosynthesis and mineral nutrient absorption. Biol. Trace. Elem. Res 142: 67-76.

Cooke J., Leishman M.R., 2011. Is plant ecology more siliceous than we realise? Trends Plant Sci. 16: 6168.

CorNIC G., 1994. Drought stress and high light effects on leaf photosynthesis. In: Photo-inhibition of photosynthesis. N.R. Baker and J.R. Bowyer (eds) Oxford BIOS, Scientific Publishers Ltd.: 297-313.

Epstein E., 2009. Silicon: its manifold roles in plants. Ann. Appl. Biol. 155: 155-160. 
Gao D., Cai K., Chen J., Luo S., Zeng R., Yang J., Zhu X., 2011. Silicon enhances photochemical efficiency and adjusts mineral nutrient absorption in Magnaporthe oryzae infected rice plants. Acta Physiol. Plant. 33: 675-682.

Gijón M.C., Gimenez C., Perez-López D., Guerrero J., Couceiro J.F., Moriana A., 2010. Rootstock influences the response of pistachio (Pistacia vera L. cv. Kerman) to water stress and rehydration. Sci. Hort. 125: 666-671.

Gijón M.C., Gimenez C., Perez-López D., Guerrero J., Couceiro J.F., Moriana A., 2011. Water relations of pistachio (Pistacia vera L.) as affected by phenological stages and water regimes. Sci. Hort. 128: 415-422.

Gong H., Zhu X., Chen K., Wang S., Zhang C., 2005. Silicon alleviates oxidative damage of wheat plants in pots under drought. Plant Sci. 169: 313-321.

Gong H.J., Chen K.M., Zhao Z.G., Chen G.C., Zhou W.J., 2008. Effects of silicon on defence of wheat against oxidative stress under drought at different developmental stages. Biol. Plant. 52: 592-596.

Goto M., Ehara H., Karita S., Takabe K., Ogawa N., Yamada Y., 2003. Protective effect of silicon on phenolic biosynthesis and ultraviolet spectral stress in rice crop. Plant Sci. 164: 349-356.

Gunes A., Inal A., Bagci E.G., Coban S., 2007. Silicon mediated changes on some physiological and enzymatic parameters symptomatic of oxidative stress in barley grown in sodic-B toxic soil. J. Plant Physiol. 164: 807-811.

Habibi G., Hajiboland R., 2010. Photosynthetic characteristics and antioxidative responses in three species of Crassulaceae following drought stress. J. Sci. I.R. Iran 21: 205-212.

HAJiBOLAND R., 2012. Effect of micronutrient deficiencies on plants stress responses. In: Abiotic stress responses in plants: metabolism, productivity and sustainability. P. Ahmad and M.N.V. Prasad (eds), Springer, New York:. 283-331.

Hattori T., Inanagaa S., Arakib H., 2005. Application of silicon enhanced drought tolerance in sorghum bicolor. Physiol. Plant. 123: 459-466.

Hattori T., Sonobe K., Inanaga S., An P., Tsuji W., Araki H., EneJi A.E., Morita S., 2007. Short term stomatal responses to light intensity changes and osmotic stress in sorghum seedlings raised with and without silicon. Environ. Exp. Bot. 60: 177-182.

Hattori T., Sonobe K., Araki H., Inanaga S., An P., Morita S., 2008. Silicon application improves water uptake by sorghum through the alleviation of stressinduced increase in hydraulic resistance. J. Plant Nutr. 31: 1482-1495.

JAISWAL P.C., 2004. Soil, plant and water analysis. Kalyani Publishers, New Delhi.

Krause G.H., Jahns P., 2004. Non-photochemical energy dissipation determined by chlorophyll fluorescence quenching: characterization and function. In:
Chlorophyll a fluorescence: A signature of photosynthesis. G.C. Papageorgiou and P. Govindjee (eds), Springer, Dordrecht: 463-495.

Liang Y., Sun W., Zhu Y.G., Christie P., 2007. Mechanisms of silicon-mediated alleviation of abiotic stresses in higher plants: A review. Environ. Pollut. 147: 422-428.

Liang Y.C., Chen Q., Liu Q., Zhang W.H., Ding R.X., 2003. Exogenous silicon ( $\mathrm{Si}$ ) increases antioxidant enzyme activity and reduces lipid peroxidation in roots of salt-stressed barely (Hordeum vulgare L.). J. Plant Physiol. 160: 1157-1164.

Liang Y.C., Zhang W.H., Chen Q., Liu Y.L., Ding R.X., 2006. Effect of exogenous silicon (Si) on H-ATPase activity, phospholipids and fluidity of plasma membrane in leaves of salt-stressed barley (Hordeum vulgare L.). Environ. Exp. Bot. 57: 212-219.

MA J.F., 2004. Role of silicon in enhancing the resistance of plants to biotic and abiotic stresses. Soil Sci. Plant Nutr. 50: 11-18.

Ma J.F., YamaJi N., 2006. Silicon uptake and accumulation in higher plants. Trends Plant Sci. 11: 392-397.

Matichenkov V.V., Calvert D.V., Snyder G.H., 2000. Effect of Si fertilization on growth and $\mathrm{P}$ nutrition of bahiagrass. Proc. Soil. Crop. Sci. Soc. Florida 60: 30-36.

Maxwell K., Johnson G.N., 2000. Chlorophyll fluorescence - a practical guide. J. Exp. Bot. 51: 659668.

Reddy A.R., Chaitanya K.V., Vivekanandan M., 2004. Drought-induced responses of photosynthesis and metabolism in higher plants. J. Plant Physiol. 161: 1189-1202.

RIEGER M., 1995. Offsetting effects of reduced root hydraulic conductivity and osmotic adjustment following drought. Tree Physiol. 15: 379-385.

Sheibani A., 1994. Pistachio production in Iran. Acta Hort. 419: 14-15.

Shen X., Zhou Y., DuAn L., Li Z., Eneji A.E., Li J., 2010. Silicon effects on photosynthesis and antioxidant parameters of soybean seedlings under drought and ultraviolet-B radiation. J. Plant Physiol. 167: 12481252.

Shi X.H., Zhang C.C., Wang H., 2005. Effect of Si on the distribution of $\mathrm{Cd}$ in rice seedlings. Plant Soil 272: 53-60.

ŚlesaK I., LibiK M., Karpinska B., KarpinsKi S., MisZALSKI Z., 2007. The role of hydrogen peroxide in regulation of plant metabolism and cellular signalling in response to environmental stresses. Acta Biochim. Pol. 54: 39-50.

Snyder G.H., Matichenkov V.V., 2007. Silicon. In: Handbook of plant nutrition. A.V. Barker and D.J. Pilbeam (eds), Taylor and Francis Group, CRC Press, Boca Raton:. 551-568. 
Sonobe K., Hattori T., An P., Tsuji W., Eneji A.E., Kobayashi S., Kawamura Y., Tanaka K., Inanaga S., 2011. Effect of silicon application on sorghum root responses to water stress. J. Plant Nutr. 34: 71-82.

Tang A.C., Kawamitsu Y., Kanechi M., Boyer J.S., 2002. Photosynthetic oxygen evolution at low water potential in leaf discs lacking an epidermis. Ann. Bot. 89: 861-870.
Waraich E.A., Amad R., Ashraf M.Y., Ahmad M., 2011. Improving agricultural water use efficiency by nutrient management. Acta Agr. Scand. 61: 291-304.

Yordanov I., Velikova V., Tsonev T., 2003. Plant responses to drought and stress tolerance. Bulg. J. Plant Physiol. 29: 187-206.

Received July 18, 2012; accepted December 16, 2012 